\title{
Overcoming Competitive Inertia: Board Composition And Strategic Persistence
}

William Kline, Temple University, USA

Todd Wadhams, Temple University, USA

\begin{abstract}
This study examined whether the board of directors had an impact on the trajectory of organizational strategy, where the composition of the board might influence the likelihood of pursuing or halting a persistent, unchanging strategy. Our data suggest that a board that exhibited moderate agency-orientation displayed a more positive relationship to strategic persistence than either a neutral board or a strong agency-focused board. This finding may indicate that a neutral board, may benefit from the cooperation required to reach agreement and that a moderately agency-oriented board may not be able to effectively reap the benefits of either control or collaboration and may only serve as window dressing in its purported function of representing shareholder interests.
\end{abstract}

Keywords: Competitive Inertia; Board Composition; Persistence; Organizational Change

\section{INTRODUCTION}

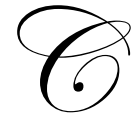

orporate boards and top executives are under tremendous pressure to maintain or extend periods of strong financial performance. Not surprisingly, executives and boards have a tendency to maintain the status quo and continue policies and strategies that have been successful in the past. This tendency, called strategic persistence, has gotten considerable attention by researchers over the years. If fact, numerous researchers have found strategic persistence in industries ranging from the software industry to the furniture industry (Finkelstein and Hambrick 1990; Lant, Milliken et al. 1992; Boeker 1997). Building upon this foundation, others have examined strategic persistence during periods of radical change (Audia, Locke et al. 2000; Hill and Rothaermel 2003; Nickerson and Silverman 2003). Still others have focused on the behavioral and psychological biases exhibited by top management teams (TMTs) and boards in making strategic decisions (Staw, McKechnie et al. 1983; Westphal and Bednar 2005).

It is against this backdrop that we examine board composition and strategic persistence. More specifically, we integrate the findings in the strategic persistence literature with the contrasting approaches of agency and stewardship theory in the corporate governance literature. In doing so, we build upon foundational theory of strategic persistence while providing additional evidence of the benefits and/or consequences of popular board structures. Thus, for the purpose of the study, we examine whether boards, classified as exhibiting agency tendencies or stewardship tendencies, influence the phenomenon called strategic persistence.

\section{THEORETICAL BACKGROUND}

Prior studies have shown that organizational strategic persistence can be attributed to a number of factors, including past success reinforcing current action sets (Lant, Milliken et al. 1992; Boeker 1997; Audia, Locke et al. 2000), firm inability to adapt to environmental change (Hill and Rothaermel 2003; Nickerson and Silverman 2003), and managerial attributions, discretion, and control (Pfeffer 1981; Mintzberg 1983; Finkelstein and Hambrick 1990). Finkelstein and Hambrick defined strategic persistence as "the extent to which a firm's strategy remains stable over time." While strategic persistence may sustain firm performance during periods of environmental stability, dysfunctional persistence following a radical environmental change causes firm performance to decline relative to industry competitors (Audia, Locke et al. 2000; Nickerson and Silverman 2003). Theories as diverse as upper 
echelon theory, behavioral psychology and managerial cognition, and organizational dynamics have been utilized to describe how strategic persistence occurs and its impacts on firm performance in changing environmental conditions, but the internal mechanisms for controlling or halting cycles of dysfunctional persistence have received little research attention. Research into strategic reorientation and firm underperformance in relation to control of the firm has focused on displacement of the management team through externally motivated actions such as hostile takeovers, acquisitions, and forced succession. Studies on the topic of executive succession have demonstrated that replacement of the CEO may bring about strategic change (Brown 1982; Tushman, Virany et al. 1985; Kesner and Sebora 1994; Bigley and Wiersema 2002), inferring that any strategic persistence that might have existed would be stopped. The board of directors serves as the primary internal, lower cost control mechanism available to shareholders through which they may influence firm strategic direction. Bigley and Wiersema (2002) found a positive association between outside board members and the likelihood of strategic reorientation after a change in executive leadership. The effects of board independence, implying a higher degree of monitoring and external control, on firm performance have been studied, but there has been no examination of the effect of board composition on strategic persistence.

Finkelstein and Hambrick (1990) use upper echelon theory (Hambrick and Mason 1984) to argue that strategic persistence is a function of managerial decision making and managerial discretion of the top management team. The dominant coalition (Cyert and March 1963) of top managers, consisting of the CEO and other firm executives holding directorships on the board, develops a shared understanding of the organization and its operating environment and implements strategy based on this common perspective or organizational paradigm (Pfeffer 1983). As the length of team tenure together increases, goal congruence and higher order routines become harmonized. A history of success serves to reinforce organizational strategic action sets and routines in concordance with the reinforcement-expectancy model of learning (Cyert and March 1963; Prahalad and Bettis 1986). Long tenures can cause managers to develop habits that rely more on past experience than new stimuli and reduce the adoption of novel or unique strategies (Katz 1982). Finkelstein and Hambrick's study demonstrated a relationship between TMT tenure and firm strategic persistence in high discretion industries (Finkelstein and Hambrick 1990).

The firm is a nexus of contracts (Jensen and Meckling 1976; Fama 1980), within which multiple stakeholder groups use their power to assert control over the organization (Pfeffer 1981; Finkelstein 1992), which serves to limit the unitary control of the TMT group of internal corporate elites. The will of internal managers to maintain their locus of control and autonomy is evidenced in the accumulation of takeover defenses in the temporal distance from the firm IPO (Field and Karpoff 2002). Shareholders of the firm may utilize external control actions such as hostile takeovers and proxy fights to displace underperforming leadership, but they will only pursue external control options when the costs of internal control mechanisms become too high (Walsh and Seward 1990). The primary internal control mechanism available to shareholders is the board of directors, through which they might influence organizational strategy and correct dysfunctional strategic persistence.

The role of the board in U.S. corporations has long been a source of study and debate. Where European firms maintain a dual board system, with one board serving in an advisory capacity and the other monitoring the TMT, U.S. boards perform both functions (Sundaramurthy and Lewis 2003; Adams and Ferreira 2007). A board monitors the TMT to align the interests of the principal and agent - the shareholders and the managers, respectively - and to control moral hazard (Jensen and Meckling 1976; Eisenhardt 1989). Agency theorists argue that information asymmetries within the principal-agent relationship lead to the misalignment of interests between parties, and that the delegation of responsibilities may be problematic due to misalignment of goals between the principal and agent, the inability of the principal to verify the agent is acting appropriately, and divergent attitudes toward risk (Eisenhardt 1989). Proponents argue that agency theory is a control approach whereby an independent party monitors and constrains self-serving behavior, without which agents will seek situations and arrangements that best suit their self interest, oftentimes to the detriment of the principal.

In contrast, resource dependency and stewardship theories hold that the role of directors is to provide support to the organization and the TMT through advising and access to resources. Resource dependence theory has human and relational capital of the board members as antecedents of resource provisioning and holds that the legitimacy, expertise, advise, and external contacts provided by board members impact firm performance through reducing external contingencies, diminishing uncertainties, and lowering transaction costs (Pfeffer and Salancik 
1978; Hillman and Dalziel 2003). Donaldson (1990) argues under stewardship theory that the goal of governance is to find an organizational structure that allows coordination to be achieved most effectively. The definition of economic man as opportunistic and subject to moral hazard is too narrow and does not account for cooperation and collaboration between managers and owners (Donaldson and Davis 1991; Davis, Schoorman et al. 1997). The primary function of board members within these paradigms is enablement of managers to achieve successful organizational outcomes rather than monitoring to control opportunistic behavior.

Attention to the roles and function of the board of directors increased with the passage of the SarbanesOxley Act. Adhering to the agency theory tenet that independent directors are more effective at monitoring the actions of executives, Sarbanes-Oxley introduced legal requirements regarding the number of outside directors appointed to the board. Though the effectiveness of outside directors at monitoring has been questioned due to their membership in the corporate elite and potential for social sanctioning (Westphal and Khanna 2003) and their lack of familiarity with organizational routines (Coles, Daniel et al. 2006; Adams and Ferreira 2007), they are still held to be better at limiting opportunistic behavior than their inside and affiliated counterparts. The proportion of outside directors has also increased due to the growing ownership and power of large institutional investors, whose large positions limit their ability to easily divest their holdings and therefore increase their interest in the control and performance of the firm (Hansen and Hill 1991; Gompers and Metrick 2001). The monitoring activities and struggle for power by independent board members act as an internal control mechanism which limits managerial discretion.

Outside directors, who are not invested in or constrained by internal organizational routines and cognitions, provide environmental scanning (Dutton and Dukerich 1991; Miller and Chen 1994) and different information sources in addition to monitoring. The information and environmental awareness brought by outside directors serve as a counterbalance to simplified general managerial rules (Ranson, Hinings et al. 1980) that become reinforced by the tenure of the top management team (Finkelstein and Hambrick 1990). Inside and affiliated directors, on the other hand, are more likely to share the same managerial cognitions as the executive team (Smith, Smith et al. 1994; Knight, Pearce et al. 1999). Those members of the board closely associated with the TMT and sharing similar cognitive constructions of the organization and similar social networks are also less likely to engage in external environmental scanning to assess external market conditions. Inside and affiliated directors will tend to support and reinforce the status quo, enabling the TMT to pursue a course of strategic persistence. Independent, outside directors will be more focused on corporate performance and less invested in maintaining organizational routines and status quo, and thus will be more likely to monitor and take action to correct dysfunctional strategic persistence, especially under circumstances of changing environmental conditions.

H1: Organizations with a board that is comprised of more outside, independent directors than inside and affiliated directors (an agency-focused, monitoring board) will be negatively associated with the existence of strategic persistence.

H2: Following a discrete and radical environmental change, organizations with a more independent board composition (agency-focused, monitoring board) will be more likely to undergo strategic reorientation.

A U.S. board maintains competing responsibilities, balancing monitoring and collaborative advising activities, where overemphasis on either approach limits benefits and increases costs (Zajac and Westphal 1994; Sundaramurthy and Lewis 2003), which may negatively impact firm performance. While independent directors may be more effective at monitoring, inside and affiliated directors can facilitate coordination through knowledge of organizational routines. Coles et al. (2006) argued that firms with greater levels of complexity and high tacit knowledge requirements need more advising input that is provided by internal board members and showed a relationship between optimal board size and board composition and firm performance. These results provide support for the stewardship conception of the board where the focus is upon collaboration and coordination (Donaldson 1990; Davis, Schoorman et al. 1997). As the composition of the board shifts towards insider representation, the threat of conformity to organizational routines that performed well in the past, shared managerial cognition, and reduced environmental scanning and information processing routines (Dutton and Dukerich 1991; Miller and Chen 1994) reduce the likelihood that managers will pursue strategic reorientation, even under conditions of radical environmental change. In providing solidarity and support to existing management, a stewardship- 
oriented board will likely reinforce existing practices even in the face of organizational decline (Sundaramurthy and Lewis 2003).

H3: Organizations with a board that is comprised of more inside and affiliated directors than outside, independent directors (a stewardship-oriented board) will be associated with higher firm levels of strategic persistence and will be less likely to undergo strategic reorientation.

H4: Following a discrete and radical environmental change, organizations with a more insider board composition (stewardship-oriented board) will under perform in their industry and take longer to undertake strategic reorientation.

\section{METHOD}

\section{Sample}

Our sample consisted of the 100 firms comprising the S\&P 100 index for the five-year period from 2002 through 2006. The range of the five-year period of observations was selected to capture any change in board composition towards more agency-focused control in response to the passage of the Sarbanes-Oxley Act and the subsequent effects on strategic persistence. Thus, our original sample included 100 companies with five annual observations each for a total of 500 observations. We selected a five-year time period to remain consistent with previous studies pertaining to strategic persistence (Finkelstein and Hambrick 1990; Audia, Locke et al. 2000). The S\&P 100 index provided a broad sampling of firms in various industries with publicly available financial and board composition data.

We gathered pertinent financial statement and board composition data from the Compustat North America, the Compustat Executive Compensation, and the RiskMetrics Group Historical Directors databases. In addition, we relied on publicly available Securities and Exchange Commission filings to supplement these data sources. In the event that data was not available for a specific variable, we eliminated the associated company from the sample. After adjusting for missing data, 215 observations remained which allowed for the five-year calculation of strategic persistence for 43 companies.

\section{MEASURES}

\section{Dependent Variable}

In operationalizing Strategic Persistence, we relied upon the definition and construct provided by Finkelstein and Hambrick (1990) to measure how a firm's strategy remains fixed over time. Thus, for the purpose of this study, we defined strategic persistence as a composite measure that captures the strategic indicators (1) advertising intensity (advertising/sales), (2) research and development intensity (R\&D/sales), (3) plant and equipment newness (net PP\&E/gross PP\&E), (4) nonproduction overhead (SGA expenses/sales), (5) inventory levels (inventories/sales), and (6) financial leverage (debt/equity). These measures were chosen because they are controllable by top managers, they have a major effect on performance, and they influence a firm's strategic profile, and therefore represent a pattern in a stream of important decisions (Mintzberg 1978). Each of these measures has been utilized previously in the strategic management literature (Schendel and Patton 1978; Finkelstein and Hambrick 1990; Audia, Locke et al. 2000).

Once the above mentioned strategic measures were calculated, a composite strategic persistence measure was estimated in concordance with Finkelstein and Hambrick's (1990) computations. First, we calculated the variance for each measure over the five-year period from 2002 through 2006, where $(t)$ represented the focal year 2003 and $t-1$ through $t+3$ represent the five-year range. Next, the variance of each measure was standardized (mean=0, standard deviation=1) by industry, using 2-digit SIC codes to segment industry groups, and multiplied by (-1) to appropriately represent the concept of persistence. The standardized variance scores captured the variability in strategic decision patterns over time relative to industry norms. Finally, all six of the standardized indicators were summed to yield an aggregate estimate of strategic persistence (SP1) (Finkelstein and Hambrick 1990). 
The broad range of industries represented by companies in our data set affected the availability of strategic measures, specifically advertising and R\&D intensity, as industry differences and practices affect the emphasis or use of these strategic capabilities. Similar to Finkelstein and Hambrick (1990), we estimated a second measure of strategic persistence $(S P 2)$, which consisted of all the above mentioned measures except advertising intensity and R\&D intensity.

\section{Independent Variable}

Board Composition was estimated from data drawn from the RiskMetrics Group Historical Directors (RGHD) database. The RGHD database provided key board member information including name, age, title, and board member classification as independent, employee or affiliate. For the purpose of this study, we utilized board member definitions developed by Huson, Parrino, and Starks (2001), and Lehn, Patro, and Zhao (2004), which define independent directors as those who are not current or former employees of the firm or relatives of current employees, or those who are not currently employed at an accounting firm, commercial bank, investment bank, insurance company, law firm, or consulting firm. The definition assumes that a board member employed at a professional services or finance firm is most likely affiliated with the firm through services provided under contract and therefore depends upon management's discretion for continued gain. The RGHD database definitions of board member classifications appear to be consistent with these definitions.

Since employees, former employees, and affiliated directors may have the potential to gain from their relationship with the firm either in the present or in the future, we argue that only those directors classified as independent should count as board members who may effectively monitor management in accordance with agency tenets. We calculated the degree of agency-focus of the board as a ratio of outside directors to total number of board members, where lower percentages represented stewardship-oriented boards and higher percentages represented agency-oriented boards, for the focal year $(t)$. These ratios were utilized to develop two separate scales of board monitoring and advising behavior.

The first scale utilized a log transformation of the direct agency-focus percentages [ $\ln (B O A R D \% /(1-$ $B O A R D \%)$ ] as a measure of board orientation based on composition $(B D)$. Performing a log transformation produced a continuous scale measurement of orientation where positive values represented an agency-oriented board, negative values denoted a stewardship-orientation, and a value of zero indicated a neutral or balanced board of insiders and outsiders. This measure was used to establish a primary relationship between board monitoring tendencies and the existence of strategic persistence. An agency-oriented board should exhibit a negative relationship to measures of strategic persistence, as their access to external information, lack of encumbrance by organizational routines and paradigms, and monitoring role (Fama and Jensen 1983; Walsh and Seward 1990; Beatty and Zajac 1994) should limit or counteract management resistance to strategic reorientation. Conversely, a stewardship-oriented board, which is embedded in organizational routines and may suffer from reduced environmental scanning or from pluralistic ignorance (Miller and McFarland 1987; Miller and Nelson 2002), should exhibit a positive relationship to strategic persistence.

The second scale classified boards as either Agency or Stewardship based on the agency-focus percentages, where lower percentage boards dominated by employee and affiliate directors were designated as Stewardship boards and higher percentage boards comprised of more outside, independent directors were categorized as Agency boards. Five categories attempted to capture the degree of power held between inside and outside directors: (1) Strong Stewardship $(S S)=0 \%$ to $20 \%$ independent directors, (2) Moderate Stewardship $(M S)=>20 \%$ up to $40 \%$, (3) Neutral $(N)=>40 \%$ up to $60 \%$, (4) Moderate Agency $(M A)=>60 \%$ up to $80 \%$, and (5) Strong Agency $(S A)=$ $>80 \%$ independent directors. This measure tested whether strategic persistence is associated with the degree of power wielded by the board subgroup responsible for a particular function (monitoring vs. advising), and provides a pseudo-test of the effect of the degree of agency-orientation in overcoming strategic persistence.

\section{Control Variables}

Size influences the firm's ability to alter organizational structure and strategy. Firms with many employees face bureaucratic momentum (Mintzberg 1978) and often have difficulty affecting change (Aldrich 1979). Size was 
calculated as the number of employees (in thousands) in the focal year ( $t$ ) of our study.

CEO Tenure measured the number of years a CEO had held his/her position as of the focal year $(t)$. Longer tenures may increase the likelihood that an organization will continue to pursue an existing strategy (Finkelstein and Hambrick 1990), whether due to confidence in the current action set engendered by past success (Lant, Milliken et al. 1992; Miller and Chen 1994) or simply due to the CEO's own resistance to change (Katz 1982). Our measure of tenure focused solely upon the single executive at the head of the firm, which differs from Finkelstein and Hambrick's (1990) approach that considered the tenure and shared cognitions of the dominant coalition of managers. Their operationalization of the dominant coalition included all internal executives of the firm who were also members of the board. Our construct of board composition accounted for insiders on the board and the relative power they wield, which addressed our inquiry into the association of board composition to strategic persistence. Inclusion of insider board member tenure into a composite tenure measure would likely dilute any relationship between board composition and our variable of interest. In recognition of Finkelstein and Hambrick's findings, we included CEO tenure to control for its effect on persistence.

CEO Turnover captured a change in organizational leadership brought about by CEO succession, whether due to retirement, resignation, or termination. While new CEOs that were groomed as heir apparent and promoted internally may be less likely to pursue strategic reorientation (Bigley and Wiersema 2002), most studies of CEO succession events have found a higher incidence of strategic reorientation after a change in leadership (Helmich and Brown 1972; Brown 1982; Tushman, Virany et al. 1985; Kesner and Sebora 1994). This variable controlled for the negative effect on strategic persistence associated with a succession event and a new CEO's strategic initiatives. Since persistence is an effect that occurs and must be measured over time, our analysis only considered turnover events that transpired during the first three years $(t-1$ to $t+1)$ of the sample.

Past Performance where a firm has a history of success reduces the likelihood that a firm will reorient its strategy (Lant, Milliken et al. 1992; Miller and Chen 1994). Five-year average ROE and ROA measures were included as control variables to address the past performance impact on strategic persistence. Each ratio was standardized by subtracting sample industry means and then dividing by sample industry standard deviations (Finkelstein and Hambrick 1990).

Slack captures the availability of flexible resources which impacts managerial discretion. We considered both short-term (working capital/sales) and long-term (debt/equity) measures of slack for use in this study. However, we determined that the long-term measure of slack was more appropriate because we believe that longterm strategic decisions that reflect persistence over time have a stronger relationship with long-term debt-to-equity financing decisions than with short-term working capital management policies.

Two-digit Standard Industry Classification (SIC) codes were utilized to control for differences in performance and fundamentals across industries represented by the sample. First, the two-digit SIC codes facilitated the classification of firms into industry segments which were employed in standardizing variances of the individual strategic indicators that underlie our strategic persistence measures (SP1 and SP2). Second, the SIC codes controlled for inter-industry differences amongst firms in our primary regression analyses.

\section{DATA ANALYSIS}

In order to complete our analysis, it was necessary to utilize models which can manage the cross-sectional and longitudinal dimensions of pooled data. Consistent with Finkelstein and Hambrick (1990), we relied upon methods developed and discussed by Balestra and Nerlove (1966), Wallace and Hussain (1969), Maddala (1977), and Mundlak (1978) for managing slope coefficient variation over time and violation of the assumption of independence of observations (Hannan and Young 1977) inherent in pooled data sets. This approach is necessary because ordinary least squares (OLS) estimation effectively ignores the pooled nature of the data and treats all the observations as though they were independent (Brown 1982). Given this, as well as the serial correlation from the times series aspect of panel data, our analysis called for a GLS (generalized least squares) estimator (Nerlove 1971; Maddala 1977). 
A two-stage, hierarchical regression model was employed first to test the validity of our control model, and then to separately test the association of each of our measures of board composition with strategic persistence. The control model sought to confirm the consistency of our model and sample in demonstrating the same relationships between strategic persistence and the variables size and tenure that Finkelstein and Hambrick (1990) had found. Once the existence of strategic persistence has been established, the initial hierarchical model will examine the relationship between persistence measures (SPI and $S P 2)$ and board composition, in terms of the ratio of outside directors $(B O A R D \%)$, to assess the effect of board independence on persistence. An additional hierarchical model will test whether the degree of agency-focus or stewardship focus of the board (SS/MS/N/MA/SA) has a significant effect on strategic persistence.

\section{RESULTS}

Table 1 presents descriptive statistics (means and standard deviations) and Pearson correlation coefficients for the variables in the study. However, the significance of the correlation coefficients should be reviewed with caution given that the data was pooled (Finkelstein and Hambrick 1990). Similar to Finkelstein and Hambrick's (1990) findings, firm size was positively and significantly correlated with our measure of strategic persistence and slack was negatively correlated though not significantly. Our initial analysis did not show an association between persistence and our measure of tenure, contrary to prior research. Of note is that average CEO tenure in our sample was just 5.3 years with a standard deviation of 4.3 years, considerably less than the 22 years of tenure (s.d. of 12 years) within the TMT as reported by Finkelstein and Hambrick (1990). A number of reasons may account for the difference, with the primary being that the TMT tenure measure included each team member's entire length of employment with the firm whereas our CEO tenure measure only accounted for years within the top management position to account for the CEO's ability to affect strategic decision making. Additionally, CEO tenure may be shorter in the long term than the overall management team and the team average may have masked this dynamic, or CEO employment length with the organization may have decreased over the intervening years to the two samples. Our more narrowly focused operationalization of tenure may be the primary reason for this variable's lack of explanatory power.

Table 1

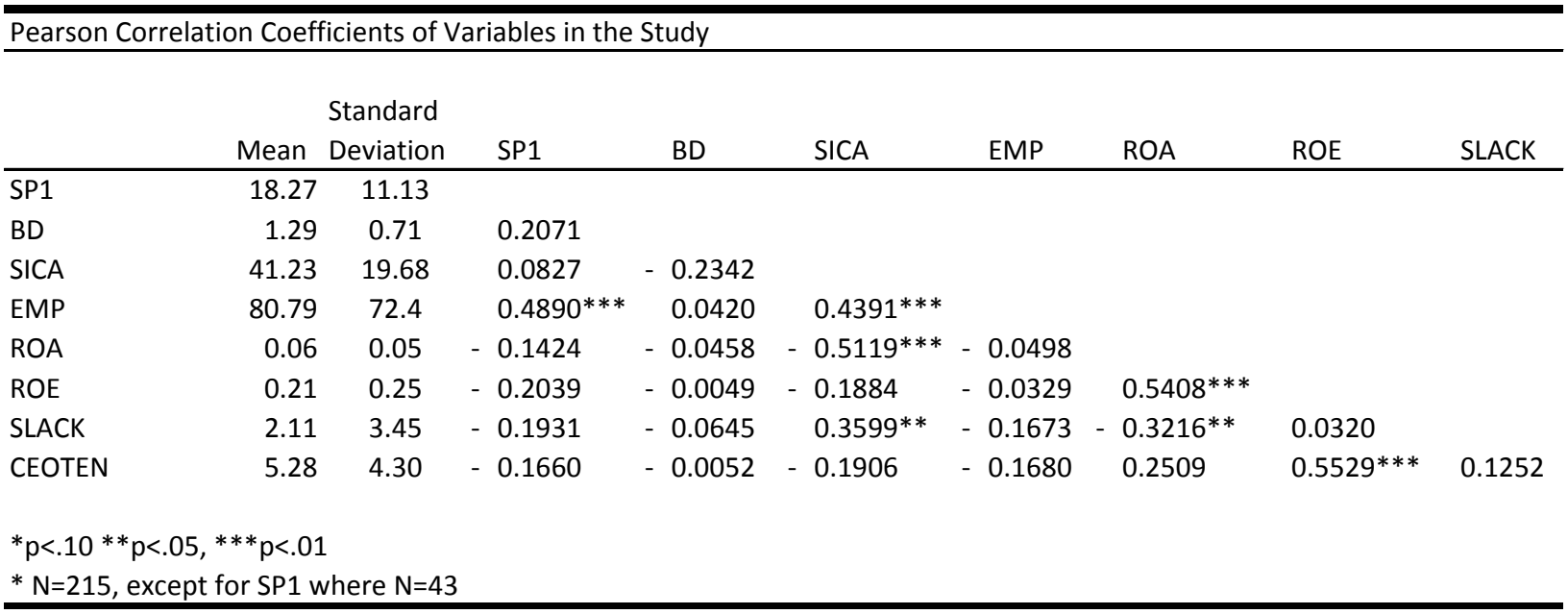

The sample of S\&P 100 firms contained other unique characteristics in addition to the differences in CEO tenure. Our original intention was to include CEO duality as a control for a CEO's additional power and influence over the board. While having the CEO serve as the chairman of the board may benefit the organization through the positive effects of unity of command, the negative effects of entrenchment (Finkelstein and Daveni 1994) may enable the CEO to persist with a dysfunctional strategic orientation. After removing firms from the sample which had missing data, the remaining 215 observations (43 firms) all exhibited CEO duality, where the CEO was also serving as the chairman of the board. While we questioned the impact of CEO duality on the likelihood of strategic 
persistence, we had to eliminate it as a control variable from the analysis due to its total lack of variance in the data set. Additional characteristics of the sample are discussed inline with the analysis results.

Table 2 presents the regression results of the control model for the strategic persistence measure SP1. This measure of strategic persistence is an aggregate of all six strategic indicators, including advertising and R\&D intensity. The overall control model was statistically significant at the $5 \%$ level, validating the existence of strategic persistence in our sample. However, only two individual variables were statistically significant in their relationship to persistence - company size and CEO turnover in 2002. Consistent with theory and prior studies (Finkelstein and Hambrick 1990; Audia, Locke et al. 2000), larger firms, which are subject to greater levels of organizational inertia, are associated with resistance to strategic reorientation.

Table 2

$\begin{array}{lc}\begin{array}{c}\text { Results of GLS Regression on the Strategic } \\ \text { Persistence of the Firm * } \\ \text { Control } \\ (\mathrm{N}=215)\end{array} \\ \text { Variable } & 186.4394 \\ \text { SICA } & 865.4612 * * * \\ \text { EMP } & 35.8040 \\ \text { ROA } & 5.3051 \\ \text { ROE } & 1.1594 \\ \text { SLACK } & 2.0733 \\ \text { CEOTEN } & 368.39 * \\ \text { CEOTURN2 } & 26.1396 \\ \text { CEOTURN3 } & 7.1078 \\ \text { CEOTURN4 } & \\ & \\ * \mathrm{p}<.10 * * \mathrm{p}<.05, * * * \mathrm{p}<.01 \\ * \mathrm{~N}=215, \text { except for } \mathrm{SP} 1 \text { where } \mathrm{N}=43\end{array}$

The positive and significant $(\mathrm{p}<0.05)$ relationship of a CEO succession event in year $t-1$, the initial year in the five-year time series, to persistence was unanticipated given the research into succession and its relationship to strategic change (Brown 1982; Tushman, Virany et al. 1985; Boeker 1997; Bigley and Wiersema 2002). Examination of the underlying data revealed that of the 43 firms in the remaining sample, 17 experienced a succession event during the five years of the study and an additional 15 firms had new CEOs at the helm in the two years proceeding the study period. These succession events equate to $39.5 \%$ of firms experiencing a turnover during the study period and $74.4 \%$ having a new CEO over the extended 7-year period. While a CEO succession event in years $t$ and $t+1$ bore no significant relationship to strategic persistence, the exponentially increasing coefficients for the successive number of years a new CEO held the top management position may indicate a hypothetical timeframe in which they may establish policy and enact strategic persistence.

Our results did not corroborate Finkelstein and Hambrick's (1990) findings of a significant relationship between tenure and strategic persistence. While the most likely cause is the construction of the CEO tenure variable as a measure of time in the position versus the team's average years employed with the firm, there is a possibility that shorter TMT tenures and more rapid turnover of CEOs may be adversely affecting the relationship. Additionally, the control model for the second strategic persistence variable, SP2 (results omitted), was not significant. The original intent of this four strategic indicator construct was to incorporate into the analysis firms 
from industries who relied more upon assets and resources (i.e. - natural gas distribution) than advertising and R\&D intensity as key components of their strategic controls (Finkelstein and Hambrick 1990). After eliminating observations with missing data from our sample, the remaining firms primarily represented pharmaceuticals, semiconductors, and petroleum refining, industries which rely heavily upon R\&D and advertising as key components of their strategy. The measure SP1 adequately captured persistence within these industries and rendered SP2 redundant and inconsequential with the lack of the two missing indicators.

Table 3

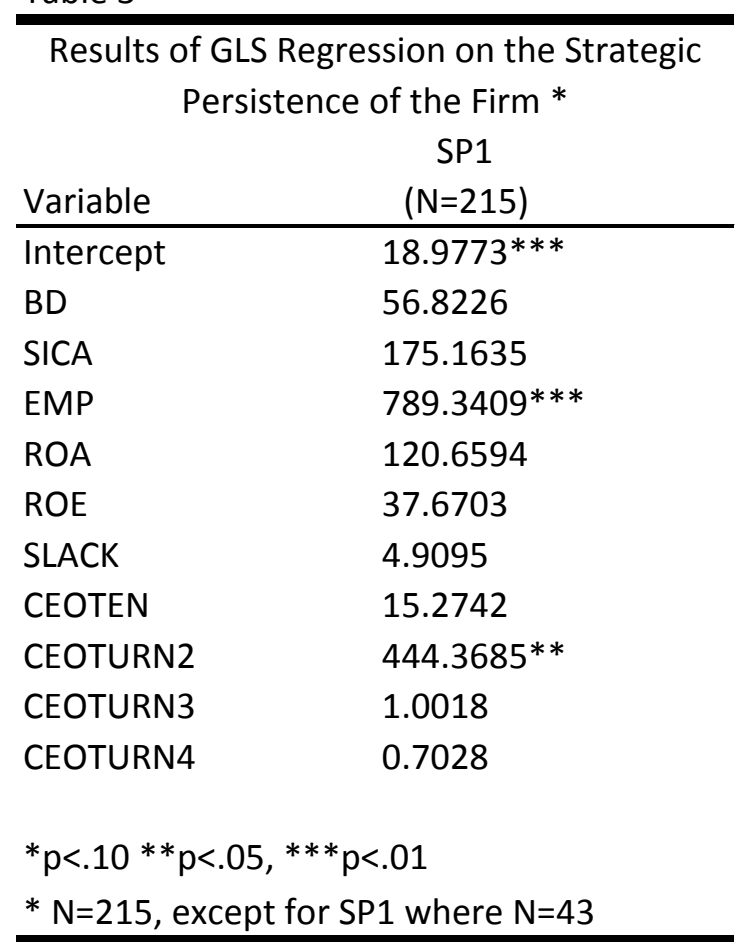

Table 3 details the results of our GLS regression analysis of strategic persistence on the log-transformed measure of board composition $(B D)$. According to our hypothesis that an agency-oriented board would be more likely to control or halt persistence, a negative and significant coefficient for $B D$ would establish a negative (positive) relationship between an agency- (stewardship-) focused board and strategic persistence. The board composition model was statistically significant at the $5 \%$ level. The control variable size $(E M P)$ remained positive and significant and the indicator for CEO succession in 2002 (CEOTURN2) exhibited an increase in both its coefficient value and its significance. The variable representing board agency-orientation versus board stewardshiporientation $(B D)$ is positive but insignificant. The positive coefficient would suggest that agency-focused boards are associated with strategic persistence and stewardship-focused boards are associated with reorientation. Our first hypothesis is unsupported.

The distribution of agency-oriented boards and stewardship-oriented boards in our sample may have been a confounding factor in our results. Within the 215 observations over the five-year period, 37 of the remaining 43 firms had either moderate agency $(M A=21)$ or strong agency $(S A=16)$-focused boards. The balance of 6 firms all exhibited neutral boards (\# of inside directors $=\#$ of outside directors), and no firms in the remaining sample maintained a stewardship-oriented board. While a small portion of firms in the original 500 observations from the S\&P 100 index did have stewardship-focused boards (10 observations; 2 firms), these observations were eliminated due to missing critical data. The lack of stewardship-oriented boards in the data set reduced the analysis to a comparison of weak agency control versus strong agency control. 
Table 4

\begin{tabular}{|c|c|}
\hline \multicolumn{2}{|c|}{$\begin{array}{l}\text { Results of GLS Regression on the Strategi } \\
\text { Persistence of the Firm * }\end{array}$} \\
\hline Intercept & $21.7368^{* * *}$ \\
\hline BD1 & 0.1536 \\
\hline BD2 & 13.9101 \\
\hline SICA & 232.2446 \\
\hline EMP & $946.4557 * * *$ \\
\hline ROA & 166.8709 \\
\hline ROE & 23.2403 \\
\hline SLACK & 3.3648 \\
\hline CEOTEN & 7.2915 \\
\hline CEOTURN2 & $446.2363 * *$ \\
\hline CEOTURN3 & 13.8500 \\
\hline CEOTURN4 & 3.9399 \\
\hline \multicolumn{2}{|c|}{${ }^{*} p<.10 * * p<.05, * * * p<.01$} \\
\hline \multicolumn{2}{|c|}{ * $\mathrm{N}=215$, except for $\mathrm{SP} 1$ where $\mathrm{N}=43$} \\
\hline
\end{tabular}

Table 4 provides results for the analysis of the degree of agency (stewardship) focus of the board and its relationship to strategic persistence. As with the prior models, the degree of focus model was statistically significant (10\% level). Size (EMP) and CEO succession in 2002 (CEOTURN2) remained positive and significant, and the succession control variables again exhibited exponentially increasing coefficients for the successive number of years a new CEO held the top management position. The variables representing degree of agency/stewardship orientation ( $B D 1=$ neutral board; $B D 2=$ moderate agency; reference category=strong agency) were positive but insignificant. While the test of degree of board control in relation to strategic persistence is insignificant, the positive coefficient for a moderate agency board (BD2) in comparison to a strong agency control board (reference category) suggests that a moderate agency control board may bear a stronger relationship to strategic persistence than a strong agency board. One might infer that a strong agency-oriented board may be more effective at controlling or halting strategic persistence pursued by the top management team. The lack of significance for any of the board composition variables left our third hypothesis unsupported.

\section{DISCUSSION}

Scholars of agency theory have long argued that a critical role of the board of directors is monitoring of the top management team to reduce opportunism and moral hazard and to improve the alignment of management interests with shareholder interests. The owners of the firm seek to maximize returns generated by firm activities, which is enabled by pursuing an appropriate organizational strategy. This study examined whether the board of directors had an impact on the trajectory of organizational strategy, where the composition of the board might influence the likelihood of pursuing or halting a persistent, unchanging strategy. Strategic persistence may arise from multiple sources, from organizational inertia to managerial complacency, and dysfunctional persistence in the face of environmental change can have detrimental effects on firm performance.

Following Finkelstein and Hambrick's (1990) methodology, we established the continued existence of strategic persistence in a more recent data set and our analysis found that firm size, engendering organizational inertia, remained a factor in organizational strategic persistence. Although our main line of inquiry regarding the effect of board role orientation on strategic persistence was inconclusive, the analyses revealed a few interesting 
observations worth considering. A board that exhibited moderate agency-orientation displayed a more positive relationship to strategic persistence than either a neutral board or a strong agency-focused board. This observation suggests that a board comprised of mainly outside directors may have the political wherewithal to influence managerial decision making and alter a course of strategic persistence where control is a crucial factor in the strategy formulation process. Conversely, a neutral board, where power may be more evenly distributed between inside and outside directors, may benefit from the cooperation required to reach agreement, thus providing the organization with more strategic options through the advisory and consensus building process. A moderately agency-oriented board, with its more positive relationship to persistence, may not be able to effectively reap the benefits of either control or collaboration and may only serve as window dressing in its purported function of representing shareholder interests.

While one might expect to observe more outside director weighted boards in light of the need for owner representation given the separation of ownership and control (Berle and Means 1932), the utter lack of insiderdominated boards in the broader sample, even when considering affiliated directors as more closely aligned with managerial interests, was surprising. The dominance of agency-oriented boards might be a manifestation of change in board demographics due to Sarbanes-Oxley requirements, or the preponderance of outsider directors could be a response to a dynamic environment that requires greater access to external resources afforded by network connections of the directors. Regardless of the source of an outsider-dominated board, a theoretical expectation set forth under the tenets of agency theory is that a board of this composition performs monitoring of and to some extent exerts control over the actions of the management team. While the evidence did not establish a relationship between board composition and strategic persistence, the prevalence of persistence necessary to attain significant correlations within a sample comprised almost entirely of agency-focused boards calls into question the effectiveness of the board in its monitoring role. Potential sources of this perceived ineffectiveness include the lack of will, organizational knowledge, or political power to influence the TMT, an inability to overcome organizational inertia, a belief that the firm is pursuing beneficial strategic persistence, or an inability to identify dysfunctional strategic persistence. This study did not address the fundamental difference between beneficial persistence and dysfunctional persistence, which may have adversely affected the results as an agency-oriented board might choose to allow or to pursue strategic persistence when a firm is performing well. Future inquiries into strategic persistence might benefit from the incorporation of trends of multi-period performance to better capture the effects of past performance on persistence (Anderson, Banker et al. 2003; Banker, Ciftci et al. 2008).

In addition to the high proportion of outsider-dominated boards in the sample, the high CEO turnover rates may have impacted the analysis. Strategic persistence is a phenomenon that develops over time and thus requires a certain longevity of conditions to establish its existence. While the existence of persistence was established in the sample, the replacement of a CEO by over half of the firms during the two years proceeding and the first two years of the sample period likely diminished the relationships between tenure, managerial initiative, and strategic persistence. The high turnover rate brought firm size and organizational inertia to the fore in producing persistence and minimized the role of the management team, especially since new teams are more likely to bring about reorientation (Tushman, Virany et al. 1985). Additionally, because new CEOs are anointed by the board of directors, the positive relationship between agency-oriented boards and persistence might be a reflection of their alignment with and support of the initiatives undertaken by the new executive team.

The relationship of CEO succession and accumulating tenure to strategic persistence was also of interest. While prior studies have examined the effects of CEO succession on strategic reorientation (Tushman, Virany et al. 1985; Boeker 1997; Bigley and Wiersema 2002), few have considered the process and timeframe through which strategic persistence arises. Our regression results found that the positive relationship between a new CEO and strategic persistence increased exponentially for each additional year they were in the position, and the relationship achieved significance in the fourth year of their tenure. The impact of CEO longevity in the fourth year of their position was approximately half that of the effects of organizational inertia. These initial findings suggest a timeframe over which managerial intention and strategic reorientation devolve into persistence and provide a starting point for board reevaluation of strategic direction during the term of a CEO. 


\section{LIMITATIONS}

As with most empirical studies, there are some limitations that warrant some discussion. First, the source of our sample limits the generalizability of our findings. This lack of generalizability is due to the large size of the sample firms, as well as the broad range of industries in which they originate. While the range of industries provides some comfort about findings, industry idiosyncrasies in terms of accounting practices and policies may influence the relationship between financial performance metrics and other variables, thus, potentially making interpretation more difficult. Second, the relatively small sample of 43 companies creates some limitations as to the strength of the findings. Future research would benefit from a broader swath of firms. Third, in our efforts to capture CEO turnover, we did not distinguish between retirement, reassignment, or termination, as reasons for turnover. Accounting for these differences may provide additional information that could prove useful in the strategic persistence literature. For example, intuition suggests that termination, especially due to underperformance, would be followed by strategic change. However, turnover due to retirement, with a successor who has many years with the firm, may be linked with strategic inertia. Future research could benefit from a more multi-dimensional view of the CEO turnover variable.

In addition to these limitations, we note that an additional variable for top-management team tenure may have provided valuable information. For the purpose of this study, we relied solely of CEO tenure, which is arguably a more volatile measure.

\section{AUTHOR INFORMATION}

William Kline, Temple University, E-mail: william.kline@temple.edu. Corresponding author.

Todd Wadhams, Temple University.

\section{REFERENCES}

1. $\quad$ Adams, R. B. and D. Ferreira (2007). "A theory of friendly boards." Journal of Finance 62(1): 217-250.

2. Aldrich, H. (1979). Organizations and environments. Englewood Cliffs, NJ, Prentice-Hall.

3. Anderson, M. C., R. D. Banker, et al. (2003). "Are selling, general, and administrative costs "sticky"?" Journal of Accounting Research 41(1): 47-63.

4. Audia, P. G., E. A. Locke, et al. (2000). "The paradox of success: An archival and a laboratory study of strategic persistence following radical environmental change." Academy of Management Journal 43(5): 837-853.

5. Balestra, P. and M. Nerlove (1966). "Pooling cross section and time series data in estimation of a dynamic model - demand for natural gas." Econometrica 34(3): 585-\&.

6. Banker, R. D., M. Ciftci, et al. (2008). Managers' optimism and sticky cost behavior. Working Paper, Temple University and The University of Texas at Dallas.

7. Beatty, R. P. and E. J. Zajac (1994). "Managerial Incentives, Monitoring, and Risk Bearing: A Study of Executive Compensation, Ownership, and Board Structure in Initial Public Offerings." Administrative Science Quarterly 39(2): 313-335.

8. Berle, A. A. and G. C. Means (1932). The modern corporation and private property, New York: Commerce Clearing House, c1932.

9. Bigley, G. A. and M. Wiersema (2002). "New CEOs and corporate strategic refocusing: How experience as heir apparent influences the use of power." Administrative Science Quarterly 47(4): 707-727.

10. Boeker, W. (1997). "Strategic change: The influence of managerial characteristics and organizational growth." Academy of Management Journal 40(1): 152-170.

11. Brown, M. C. (1982). "Administrative succession and organizational performance - the succession effect." Administrative Science Quarterly 27(1): 1-16.

12. Coles, J. L., N. D. Daniel, et al. (2006). Boards: Does One Size Fit All? Journal of Financial Economics.

13. Cyert, R. M. and J. G. March (1963). A Behavioral Theory of the Firm. Englewood Cliffs, N. J., PrenticeHall. 
14. Davis, J. H., F. D. Schoorman, et al. (1997). "Toward a stewardship theory of management." Academy of Management Review 22(1): 20-47.

15. $\quad$ Donaldson, L. (1990). "The ethereal hand - organizational economics and management theory." Academy of Management Review 15(3): 369-381.

16. Donaldson, L. and J. H. Davis (1991). "Stewardship Theory or Agency Theory: CEO Governance and Shareholder Returns." Australian Journal of Management 16(1): 49-65.

17. Dutton, J. E. and J. M. Dukerich (1991). "Keeping an eye on the mirror - image and identity in organizational adaptation." Academy of Management Journal 34(3): 517-554.

18. Eisenhardt, K. M. (1989). "Agency Theory - An Assessment and Review." Academy of Management Review 14(1): 57-74.

19. Fama, E. F. (1980). "Agency problems and the theory of the firm." Journal of Political Economy 88(2): 288-307.

20. Fama, E. F. and M. C. Jensen (1983). "Separation of Ownership and Control." The Journal of Law and Economics 26(2): 301.

21. Field, L. C. and J. M. Karpoff (2002). "Takeover defenses of IPO firms." Journal of Finance 57(5): 18571889.

22. $\quad$ Finkelstein, S. (1992). "Power in Top Management Teams - Dimensions, Measurement, and Validation." Academy of Management Journal 35(3): 505-538.

23. Finkelstein, S. and R. A. Daveni (1994). "CEO duality as a double-edged sword - How boards of directors balance entrenchment avoidance and unity of command." Academy of Management Journal 37(5): 10791108.

24. Finkelstein, S. and D. C. Hambrick (1990). "Top-Management-Team Tenure and Organizational Outcomes - the Moderating Role of Managerial Discretion." Administrative Science Quarterly 35(3): 484-503.

25. Gompers, P. A. and A. Metrick (2001). "Institutional investors and equity prices." Quarterly Journal of Economics 116(1): 229-259.

26. Hambrick, D. C. and P. A. Mason (1984). "Upper Echelons - The Organization as a Reflection of its Top Managers." Academy of Management Review 9(2): 193-206.

27. Hannan, M. T. and A. A. Young (1977). "Estimation in Panel Models: Results on Pooling Cross-Sections and Time Series." Sociological Methodology 8: 52-83.

28. Hansen, G. S. and C. W. L. Hill (1991). "Are Institutional Investors Myopic - a Time-Series Study of 4 Technology-Driven Industries." Strategic Management Journal 12(1): 1-16.

29. Helmich, D. L. and W. B. Brown (1972). "Successor type and organizational change in corporate enterprise." Administrative Science Quarterly 17(3): 371-381.

30. Hill, C. W. L. and F. T. Rothaermel (2003). "The performance of incumbent firms in the face of radical technological innovation." Academy of Management Review 28(2): 257-274.

31. Hillman, A. J. and T. Dalziel (2003). "Boards of directors and firm performance: Integrating agency and resource dependence perspectives." Academy of Management Review 28(3): 383-396.

32. Huson, M. R., R. Parrino, et al. (2001). "Internal monitoring mechanisms and CEO turnover: A long-term perspective." Journal of Finance 56(6): 2265-2297.

33. Jensen, M. C. and W. H. Meckling (1976). "Theory of firm - managerial behavior, agency costs and ownership structure." Journal of Financial Economics 3(4): 305-360.

34. Katz, R. (1982). "The effects of group longevity on project communication and performance." Administrative Science Quarterly 27(1): 81-104.

35. Kesner, I. F. and T. C. Sebora (1994). "Executive Succession - Past, Present and Future." Journal of Management 20(2): 327-372.

36. Knight, D., C. L. Pearce, et al. (1999). "Top management team diversity, group process, and strategic consensus." Strategic Management Journal 20(5): 445-465.

37. Lant, T. K., F. J. Milliken, et al. (1992). "The Role of Managerial Learning and Interpretation in Strategic Persistence and Reorientation - an Empirical Exploration." Strategic Management Journal 13(8): 585-608.

38. Lehn, K., S. Patro, et al. (2004). Determinants of size and structure of corporate boards: 1935-2000. Working Paper, University of Pittsburgh and Bentley College.

39. Maddala, G. S. (1977). Econometrics. New York, McGraw-Hill: xii, 516 p.: ill. ; 24 cm. \%@ 0070394121 $\% 1$ HB139.M32. 
40. Miller, D. and M. J. Chen (1994). "Sources and consequences of competitive inertia - a study of the UnitedStates airline industry." Administrative Science Quarterly 39(1): 1-23.

41. Miller, D. T. and C. McFarland (1987). "Pluralistic ignorance: When similarity is interpreted as dissimilarity." Journal of Personality and Social Psychology 53(2): 298-305.

42. Miller, D. T. and L. D. Nelson (2002). "Seeing approach motivation in the avoidance behavior of others: Implications for an understanding of pluralistic ignorance." Journal of Personality and Social Psychology 83(5): 1066-1075.

43. $\quad$ Mintzberg, H. (1978). "Patterns in Strategy Formation." Management Science 24(9): 934-948.

44. Mintzberg, H. (1983). "Why America needs, but cannot have, corporate democracy." Organizational Dynamics 11(4): 5-20.

45. Mundlak, Y. (1978). "Pooling of time-series and cross-section data." Econometrica 46(1): 69-85.

46. Nerlove, M. (1971). "Further evidence on estimation of dynamic economic relations from a time series of cross sections." Econometrica 39(2): 359-\&.

47. Nickerson, J. A. and B. S. Silverman (2003). "Why firms want to organize efficiently and what keeps them from doing so: Inappropriate governance, performance, and adaptation in a deregulated industry." Administrative Science Quarterly 48(3): 433-465.

48. $\quad$ Pfeffer, J. (1981). Power in organizations, Marshfield, Mass. : Pitman Pub., c1981.

49. Pfeffer, J. (1983). Organizational demography. Research in Organizational Behavior. L. L. Cummings and B. M. Staw. Greenwich, CT, JAI Press. 5: 299-357.

50. Pfeffer, J. and G. Salancik (1978). The external control of organizations : a resource dependence perspective, New York : Harper \& Row, c1978.

51. Prahalad, C. K. and R. A. Bettis (1986). "The dominant logic - a new linkage between diversity and performance." Strategic Management Journal 7(6): 485-501.

52. Ranson, S., B. Hinings, et al. (1980). "Structuring of organizational structures." Administrative Science Quarterly 25(1): 1-17.

53. Schendel, D. and G. R. Patton (1978). "Simultaneous equation model of corporate strategy." Management Science 24(15): 1611-1621.

54. Smith, K. G., K. A. Smith, et al. (1994). "Top Management Team Demography and Process - the Role of Social Integration and Communication." Administrative Science Quarterly 39(3): 412-438.

55. $\quad$ Staw, B. M., P. I. McKechnie, et al. (1983). "The Justification of Organizational Performance." Administrative Science Quarterly 28(4): 582-600.

56. Sundaramurthy, C. and M. Lewis (2003). "Control and collaboration: Paradoxes of governance." Academy of Management Review 28(3): 397-415.

57. Tushman, M. L., B. Virany, et al. (1985). "Executive succession, strategic reorientations, and organization evolution - the minicomputer industry as a case in point." Technology in Society 7(2-3): 297-313.

58. Wallace, T. D. and A. Hussain (1969). "Use of error components models in combining cross section with time series data." Econometrica 37(1): 55-\&.

59. Walsh, J. P. and J. K. Seward (1990). "On the efficiency of internal and external corporate-control mechanisms." Academy of Management Review 15(3): 421-458.

60. Walsh, J. P. and J. K. Seward (1990). "On the Efficiency of Internal and External Corporate Control Mechanisms." Academy of Management Review 15(3): 421-458.

61. Westphal, J. D. and M. K. Bednar (2005). "Pluralistic Ignorance in Corporate Boards and Firms' Strategic Persistence in Response to Low Firm Performance." Administrative Science Quarterly 50(2): 262-298.

62. Westphal, J. D. and P. Khanna (2003). "Keeping directors in line: Social distancing as a control mechanism in the corporate elite." Administrative Science Quarterly 48(3): 361-398.

63. Zajac, E. J. and J. D. Westphal (1994). "The costs and benefits of managerial incentives and monitoring in large US corporations - When is more not better." Strategic Management Journal 15: 121-142. 